\title{
Streptomyces asenjonii sp. nov., isolated from hyper-arid Atacama Desert soils and emended description of Streptomyces viridosporus Pridham et al. 1958
}

\author{
Michael Goodfellow $\cdot$ Kanungnid Busarakam • Hamidah Idris • \\ David P. Labeda • Imen Nouioui - Roselyn Brown • Byung-Yong Kim • \\ Maria del Carmen Montero-Calasanz • Barbara A. Andrews • Alan T. Bull
}

Received: 10 February 2017/ Accepted: 5 May 2017/Published online: 6 June 2017

(C) The Author(s) 2017. This article is an open access publication

\begin{abstract}
A polyphasic study was undertaken to establish the taxonomic status of Streptomyces strains isolated from hyper-arid Atacama Desert soils. Analysis of the 16S rRNA gene sequences of the isolates showed that they formed a well-defined lineage that was loosely associated with the type strains of several Streptomyces species. Multi-locus sequence analysis based on five housekeeping gene alleles showed that the strains form a homogeneous taxon that is closely related to the type strains of Streptomyces ghanaensis and Streptomyces viridosporus. Representative isolates were shown to have chemotaxonomic and morphological properties consistent with their classification in the genus Streptomyces. The isolates have many phenotypic features in common, some of which
\end{abstract}

Electronic supplementary material The online version of this article (doi:10.1007/s10482-017-0886-7) contains supplementary material, which is available to authorized users.

M. Goodfellow $(\bowtie) \cdot$ K. Busarakam .

H. Idris · I. Nouioui · R. Brown ·

M. del Carmen Montero-Calasanz

School of Biology, Newcastle University, Ridley Building

2, Newcastle upon Tyne NE1 7RU, UK

e-mail: m.goodfellow@ncl.ac.uk

D. P. Labeda

National Centre for Agricultural Utilization Research, USDA ARS, Peoria, IL 61614, USA

B.-Y. Kim

Chunlab Inc., Seoul Natural University, Gwanak-ro,

Gwanak-gu, Seoul 151-742, Republic of Korea distinguish them from S. ghanaensis NRRL B-12104 ${ }^{\mathrm{T}}$, their near phylogenetic neighbour. On the basis of these genotypic and phenotypic data it is proposed that the isolates be recognised as a new species within the genus Streptomyces, named Streptomyces asenjonii sp. nov. The type strain of the species is KNN35.1 $b^{T}$ $\left(\right.$ NCIMB $15082^{\mathrm{T}}=$ NRRL B-65050 ${ }^{\mathrm{T}}$ ). Some of the isolates, including the type strain, showed antibacterial activity in standard plug assays. In addition, MLSA, average nucleotide identity and phenotypic data show that the type strains of S. ghanaensis and $S$. viridosporus belong to the same species. Consequently, it is proposed that the former be recognised as a heterotypic synonym of the latter and an emended description is given for $S$. viridosporus.

Keywords Streptomyces · Polyphasic taxonomy · Hyper-arid · Atacama Desert
A. T. Bull
School of Biosciences, University of Kent, Canterbury, Kent CT2 7NJ, UK
B. A. Andrews
Centre for Biotechnology and Bioengineering (CeBiB), Department of Chemical Engineering and Biotechnology, University of Chile, Beauchef, 851 Santiago, Chile 


\section{Introduction}

The prospect of isolating novel filamentous actinobacteria that synthesise new specialised metabolites is enhanced when bioprospecting strategies are focused on neglected and unexplored habitats (Hong et al. 2009; Tiwari and Gupta 2012; Guo et al. 2015), including desert soils (Meklat et al. 2011; Boubetra et al. 2013). The most extensive surveys of culturable actinobacterial diversity in desert biomes have been concentrated on sites in the Atacama Desert in northern Chile, the driest non-polar desert on the planet (Bull and Asenjo 2013; Bull et al. 2016). The application of a taxonomic approach to drug discovery (Goodfellow and Fiedler 2010) has been effective in the isolation of putatively novel filamentous actinobacteria from Atacama Desert habitats, some of which produce novel natural products (Bull et al. 2016; Wichner et al. 2016). Indeed, polyphasic taxonomic studies on dereplicated actinobacteria isolated from hyper-arid and extreme hyper-arid Atacama Desert soils have led to the description of novel species of Lechevalieria (Okoro et al. 2010), Lentzea (Idris et al. 2017a) and Modestobacter (Busarakam et al. 2016a) and to the detection of rare thermophilic Amycolatopsis species (Busarakam et al. 2016b). In addition, several new Streptomyces species have been described (Santhanam et al. 2012a, b, 2013; Idris et al. 2017b), one of which, Streptomyces leeuwenhoekii (Busarakam et al. 2014), encompasses strains that synthesise novel antibiotics (Nachtigall et al. 2011; Rateb et al. 2011a, b) and chaxapeptin, a new lasso peptide (Elsayed et al. 2015).

The present study was designed to establish the taxonomic position of several closely related Atacama Desert streptomycetes. These strains were the subject of a polyphasic taxonomic study which showed that they belong to a new species, Streptomyces asenjonii sp. nov.

\section{Materials and methods}

Isolation, maintenance and cultivation of strains

Isolates KNN6.11a, KNN35.1 $\mathrm{b}^{\mathrm{T}}, \quad \mathrm{KNN} 35.2 \mathrm{~b}$, $\mathrm{KNN} 48.3 \mathrm{e}$ and KNN83.e were recovered from a hyper-arid soil collected in 2012 by one of us (ATB) from the Chaxa de Laguna, Salar de Atacama near
Tocanão $\left(23^{\circ} 17^{\prime} 33^{\prime \prime} \mathrm{S}, 68^{\circ} 10^{\prime} 99^{\prime \prime} \mathrm{W}\right.$ at $2219 \mathrm{~m}$ above sea level), using the dilution plate procedure described by Okoro et al. (2009). The strains were isolated on Gauze's No.1 agar (KNN6.11a) (Zakharova et al. 2003), humic acid-vitamin agar $\left(\mathrm{KNN} 35.1 b^{\mathrm{T}}\right.$, KNN35.2b) (Hayakawa and Nonomura 1987) and SM1 agar (KNN48.3e, KNN83.e) (Tan et al. 2006) following incubation for 14 days at $28{ }^{\circ} \mathrm{C}$. Similarly, the final strain, KNN42.f, was isolated from a starchcasein agar plate (Küster and Williams 1964) following inoculation with a suspension of an extreme hyperarid soil collected by ATB in 2010 from the Yungay core region of the Atacama Desert $\left(24^{\circ} 06^{\prime} 18.6^{\prime \prime} \mathrm{S}\right.$, $70^{\circ} 01^{\prime} 55.6^{\prime \prime} \mathrm{W}$ at $1016 \mathrm{~m}$ asl). These strains, together with Streptomyces ghanaensis NRRL B12104 ${ }^{\mathrm{T}}$ (Wallhäuser et al. 1965), were maintained on yeast extractmalt extract agar (International Streptomyces Project [ISP2] medium., Shirling and Gottlieb 1966) and as suspensions of spores and hyphal fragments in $20 \%$, v/v glycerol at -20 and $-80{ }^{\circ} \mathrm{C}$. Biomass samples for most of the chemotaxonomic analyses and for the $16 \mathrm{~S}$ rRNA gene sequencing studies were prepared in shake flasks ( 180 revolutions per minute) of ISP 2 broth after incubation at $28{ }^{\circ} \mathrm{C}$ for 14 days and washed twice in distilled water. Cells for the chemotaxonomic analyses were freeze-dried and those for the sequencing studies stored at room temperature. Biomass preparations for the fatty acid analyses were harvested from shake flasks of Tryptic Soy broth (Difco) following incubation at $28^{\circ} \mathrm{C}$ for 7 days.

Phylogenetic analysis

16S rRNA gene sequencing. Genomic DNA extraction, PCR-mediated amplification of 16S rRNA genes and purification of the resultant products were carried out on all of the isolates using the procedures described by Kim and Goodfellow (2002). Identification of phylogenetic neighbours and calculation of pairwise 16S rRNA gene sequence similarities were achieved using the EzTaxon-e server (http://www. ezbiocloud.net/taxonomy; Yoon et al. 2017) and the resultant sequences aligned using the CLUSTAL W algorithm from the MEGA 6 software package (Tamura et al. 2013). Phylogenetic analyses using the maximum-likelihood (ML) (Felsenstein 1981) and maximum-parsimony (MP) algorithms (Fitch 1971) were also realised using the GGDC web server (MeierKolthoff et al. 2013a) of the DSMZ phylogenomics 
pipeline (Meier-Kolthoff et al. 2014) adapted to single genes available at http://ggdc.dsmz.de/. ML and MP trees were inferred from the alignment with RAxML (Stamatakis 2014) and TNT (Goloboff et al. 2008), respectively. The topologies of the resultant trees were evaluated by bootstrap analyses (Felsenstein 1985) based on 1000 replicates used in conjunction with treebisection-and-reconnection branch swapping and ten additional random sequence replicates for MP and rapid bootstrapping in conjunction with the auto MRE bootstopping criterion (Pattengale et al. 2010) for ML. The trees were rooted using the 16S rRNA gene sequence of Streptomyces albus subspecies albus DSM $40317^{\mathrm{T}}$ (GenBank accession number AJ621602). The $\mathrm{X}^{2}$ test implemented in PAUP* (Swofford 2002) was used to check for compositional bias. Pairwise sequence similarities were calculated using the method recommended by Meier-Kolthoff et al. (2013b) for 16S rRNA genes and a multiple sequence alignment was created with MUSCLE (Edgar 2004).

Multi-locus sequence analysis. Genomic DNA extracted from each of the isolates following growth in ISP2 broth at $28{ }^{\circ} \mathrm{C}$ was purified, as described by Idris et al. (2017a). The housekeeping genes used in previous analyses on streptomycetes (Busarakam et al. 2014; Labeda et al. 2017; Idris et al. 2017b; Labeda 2016), namely atpD (ATP synthase F1, beta subunit), gyrB (DNA gyrB subunit), $r p o B$ (RNA polymerase beta subunit), recA (recombinase A) and $\operatorname{trp} B$ (tryptophane B, beta subunit), were amplified, sequenced, purified, deposited in the GenBank database and organised using the Bacterial Isolate Genome Sequence Database BIGSdb version 1.15.4 on the ARS Microbial Genome Sequence Database server (http://199.133.98.43). The sequences of the protein loci of the strains were aligned with one another and with those of their close neighbours and phylogenetic relationships established using the ML algorithm after Idris et al. (2017a). Pairwise distances between the sequences of each locus were established using the Kimura two-parameter model (Kimura 1980). Strain pairs having MLSA evolutionary distances $\leq 0.007$ were considered conspecific based on the cut-off point empirically determined by Rong and Huang (2012, 2014), a value that corresponds to the $70 \%$ DNA:DNA threshold recommended for the delineation of prokaryotic species by Wayne et al. (1987).
Draft genome preparation and ANI calculations

The draft genome sequence of Streptomyces viridosporus NRRL $2414^{\mathrm{T}}$ was prepared following the protocol outlined in Labeda et al. (2016) with the exception that CLCbio Genomic Workbench Version 9.5.3 (CLCbio; Boston, MA) was used for contig trimming and de novo assembly. This Whole Genome Shotgun project has been deposited at DDBJ/EMBL/ GenBank under the accession MSGP00000000.

The draft genome sequence of NRRL $2414^{\mathrm{T}}$ was compared with the draft genomes sequences of $S$. viridosporus T7A (Genbank accession number AJFD00000000), S. ghanaensis ATCC $14672^{\mathrm{T}}$ (GenBank accession number ABYA00000000), Streptomyces hirsutus NRRL B-3713 ${ }^{\mathrm{T}}$ (GenBank accession number LIQT00000000), and Streptomyces cyanoalbus NRRL B-3040 ${ }^{\mathrm{T}}$ (GenBank accession number LIPS0000 0000) obtained from Genbank utilising the calculate_ani.py script (https://github.com/widdowquinn/srip ts/blob/master/bioinformatics/calculate_ani.py) which implements the methods described by Goris et al. (2007) and Richter and Rosselló-Móra (2009), with results shown in Supplemental Table S1.

Chemotaxonomy and morphology

Isolates $\mathrm{KNN} 35.1 \mathrm{~b}^{\mathrm{T}}$ and $\mathrm{KNN} 35.2 \mathrm{~b}$ were examined for spore chain arrangement and spore-surface ornamentation following growth on oatmeal agar (ISP 3 medium; Shirling and Gottlieb 1966) for 14 days at $28{ }^{\circ} \mathrm{C}$, by scanning electron microscopy (Cambridge 240 instrument), using the protocol described by O'Donnell et al. (1993). Key chemotaxonomic markers were sought using standard chromatographic procedures. All of the isolates were examined for isomers of diaminopimelic acid $\left(\mathrm{A}_{2} \mathrm{pm}\right)$ after Staneck and Roberts (1974). Strains KNN35.1b ${ }^{T}$ and KNN35.2b were analysed for menaquinone, whole cell sugar and polar lipid composition using the procedures described by Collins et al. (1985), Lechevalier and Lechevalier (1970) and Minnikin et al. (1984), respectively. S. ghanaensis NRRL $\mathrm{B}-12104^{\mathrm{T}}$, the close phylogenetic neighbour of the isolates, was included in the sugar and polar lipid analyses. Fatty acids of representative isolates, namely strains KNN35.1b ${ }^{\mathrm{T}}$, KNN35.2b and KNN42.f, and the S. ghanaensis type strain, were extracted, methylated 
and analysed using the established Sherlock Microbial Identification (MIDI) system and the ACTIN version 6 database (Sasser 1990).

\section{Cultural characteristics}

The cultural properties of the isolates were recorded on tryptone-yeast extract, yeast extract-malt extract, inorganic salts-starch, glycerol-asparagine, peptoneyeast extract-iron and tyrosine agar plates (ISP media 1-7, Shirling and Gottlieb 1966) after 14 days at $28{ }^{\circ} \mathrm{C}$. Aerial and substrate mycelial colours and those of diffusible pigments were determined by comparison against chips from the Inter-Society Colour CouncilNational Bureau of Standard Colour charts (Kelly 1964).

\section{Phenotypic tests}

The isolates and S. ghanaensis NRRL B-12104 ${ }^{\mathrm{T}}$ were examined for standard biochemical, degradative and physiological characteristics after Williams et al. (1983) and enzyme profiles determined using APIZYM kits (BioMerieux) employing a standardised inoculum corresponding to 5 on the McFarland scale (Murray et al. 1999) and the protocol provided by the manufacturer. The oxidation of carbon sources and resistance to inhibitory compounds were determined using GENIII microplates in an Omnilog device (Biolog Inc., Haywood, USA). The microplates were inoculated with cell suspensions made in a 'gelling' inoculating fluid at a cell density of $98 \%$ transmittance with a run time of 7 days in phenotypic microarray mode at $28{ }^{\circ} \mathrm{C}$. The exported data were analysed using the opm package for $\mathrm{R}$ version 1.0.6. (Vaas et al. 2012, 2013). The Biolog tests were carried out in duplicate.

\section{Antibacterial sensitivity assays}

Four of the isolates, strains KNN6.11a, KNN35.1b ${ }^{\mathrm{T}}$, KNN35.2b and KNN83.e, were examined for their ability to inhibit the growth of wild type strains of Bacillus subtilis, Escherichia coli, Pseudomonas fuorescens and Staphylococcus aureus using a standard plug assay (Fiedler 2004). The isolates were grown on yeast extract-malt extract sloppy agar $(0.8 \%$, w/v agar) for 14 days at $30{ }^{\circ} \mathrm{C}$ and then plugs were transferred to nutrient agar plates which had been inoculated with
$100 \mu \mathrm{l}$ of the wild type strains grown overnight in lysogeny broth. The inoculated plates were incubated overnight and then examined for the presence of inhibition zones around the agar plugs.

\section{Results and discussion}

The six strains isolated from the hyper-arid and extreme hyper-arid Atacama Desert soils were shown to form a well delineated subclade in the Streptomyces 16S rRNA gene tree, a relationship that was supported by all of the tree-making algorithms and by a $78 \%$ bootstrap value (Fig. 1). The isolates were found to share 16S rRNA gene sequence similarities within the range $99.85-100 \%$, which corresponds to up to 3 nucleotide (nt) differences at 1373 locations. The strains were seen to be closely related to the type strains of Streptomyces gancidicus DSM 40935 (99.5799.64\% similarity), Streptomyces pseudogriseolus DSM $40026^{\mathrm{T}}$ (99.49-99.58\% similarity), Streptomyces capillispiralis DSM 41695 ${ }^{\mathrm{T}}$ (99.49-99.57\% similarity), Streptomyces werraensis DSM $40486^{\mathrm{T}}$ (99.34-99.51\% similarity), Streptomyces minutiscleroticus DSM $40301^{\mathrm{T}}(99.05-99.15 \%$ similarity) and Streptomyces cellulosae DSM 40362 ${ }^{\mathrm{T}}$ (99.35-99.50\% similarity). These data suggest that the Atacama Desert isolates are not particularly closely related to any of their near phylogenetic neighbours in the Streptomyces 16S rRNA gene tree.

The isolates were found to belong to a distinct and homogeneous lineage in the Streptomyces MLSA gene tree based on concatenated partial sequences of the five housekeeping genes, a result supported by a $100 \%$ bootstrap value (Fig. 2). The MLSA evolutionary distances between the isolates ranged from $<0.000$ to 0.001 (Table 1), that is, well within the species level threshold of $\leq 0.007$ proposed by Rong and Huang (2012, 2014). Members of this well delineated taxon were found to be closely related to the type strains of $S$. ghanaensis DSM $40746^{\mathrm{T}}$ and S. viridosporus DSM $40243^{\mathrm{T}}$ (Pridham et al. 1958), albeit with MLSA distances well above the species cut-off point (Table 1). These results provide further evidence of the value of MLSA sequence analyses in clarifying the subgeneric relationships of Streptomyces (Guo et al. 2008; Rong and Huang 2010, 2012, 2014; Busarakam et al. 2014; Idris et al. 2017b; Labeda et al. 2014, 2017; Labeda 2016). The S. ghanaensis and S. viridosporus 


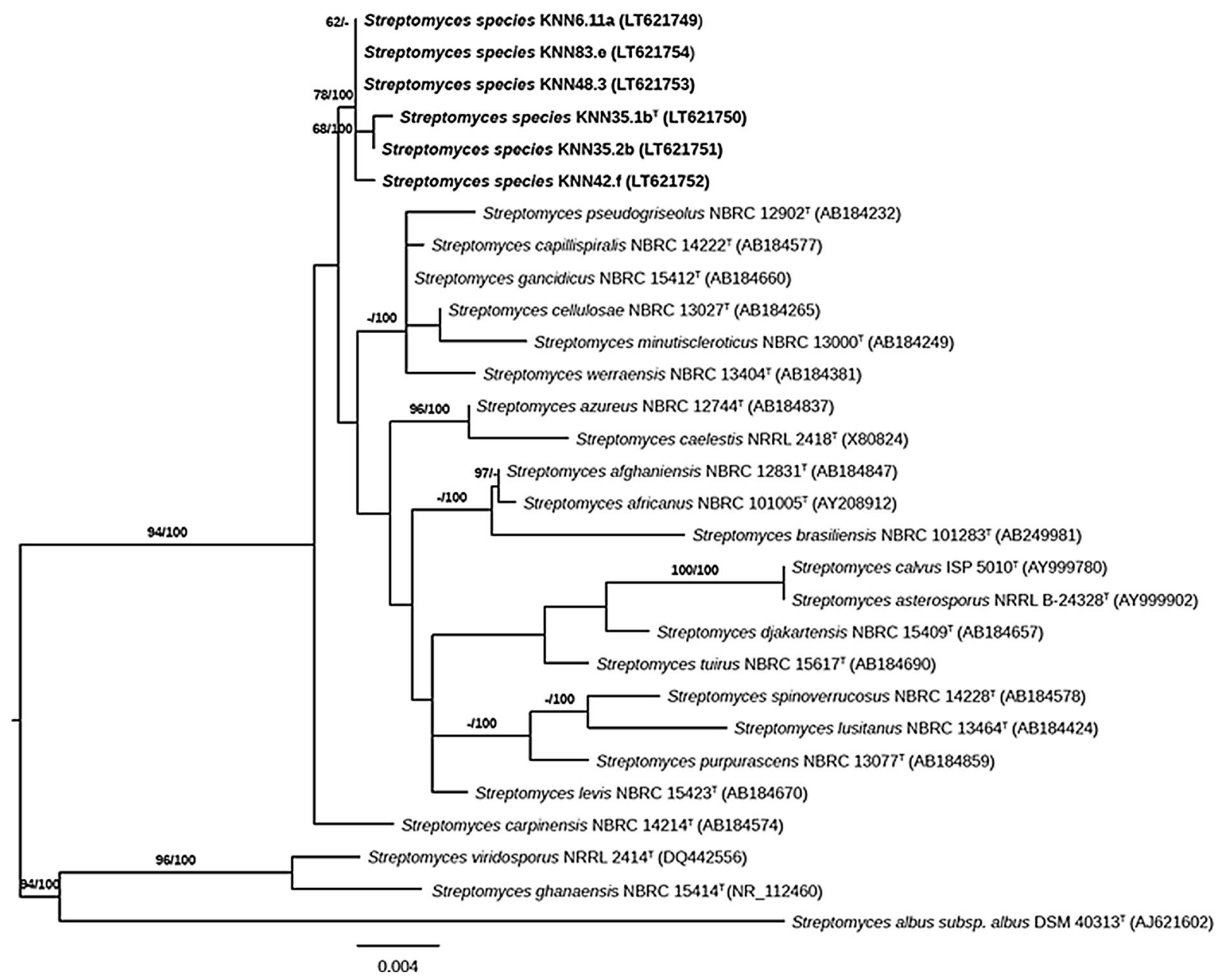

Fig. 1 Maximum-likelihood phylogenetic tree based on 16S rRNA sequences showing relationships between isolates KNN6.11a, KNN 35.1b, KNN 35.2b, KNN 42.f, KNN 48.3, and KNN83.e and between them and the type strains of the most closely related Streptomyces species, the tree was inferred using

strains formed a well-supported subclade in the $16 \mathrm{~S}$ rRNA gene tree (Fig. 1) but were not particularly closely related $(99.5 \%$ sequence similarity, $19 \mathrm{nt}$ differences), results that are clearly more apparent than real given the corresponding MLSA data.

The isolates were shown to form extensively branched substrate mycelia bearing aerial hyphae, to contain LL- $\mathrm{A}_{2} \mathrm{pm}$ as the wall diamino acid and exhibited good growth on all of the ISP media, notably on oatmeal and yeast extract-malt extract agar (Table 2). In general, the substrate mycelia were observed to be grey to yellowish white and the aerial spore mass greyish yellow or bright orange yellow, as the GTR+GAMMA model. The branches are scaled in terms of the expected number of substitutions per site. The numbers above the branches are support values when larger than $60 \%$ from ML (left) and MP (right) bootstrapping

were the diffusible pigments. Isolates $\mathrm{KNN} 35.1 \mathrm{~b}^{\mathrm{T}}$ and $\mathrm{KNN} 35.2 \mathrm{~b}$ were seen to form open spirals of hairy ornamented surfaced spores, as shown in Fig. 3. These isolates and S. ghanaensis NRRL B-12104 ${ }^{\mathrm{T}}$, their close phylogenetic neighbour, were found to have glucose, mannose, ribose and xylose in whole organism hydrolysates, whilst the $S$. ghanaensis strain was also found to contain galactose. The polar lipid patterns of these strains showed the presence of diphosphatidylglycerol, glycophospholipid, phosphatidylethanolamine, phosphatidylglycerol, phosphatidylinositol and a number of unidentified components, as shown in Figure S1. The predominant 
Fig. 2 Subtree from the Streptomyces phylogenetic tree inferred from concatenated partial sequences of the housekeeping genes $a t p D, \operatorname{gyr} B$, $r e c A, \operatorname{rpoB}$ and $\operatorname{trp} B$ in IQTree version 1.4.2 (Nguyen et al. 2015) as described by Labeda et al. (2017).

Bootstrap values less than $95 \%$ were omitted as suggested by the IQ-Tree developers. Bar scale reflects number of substitutions per site

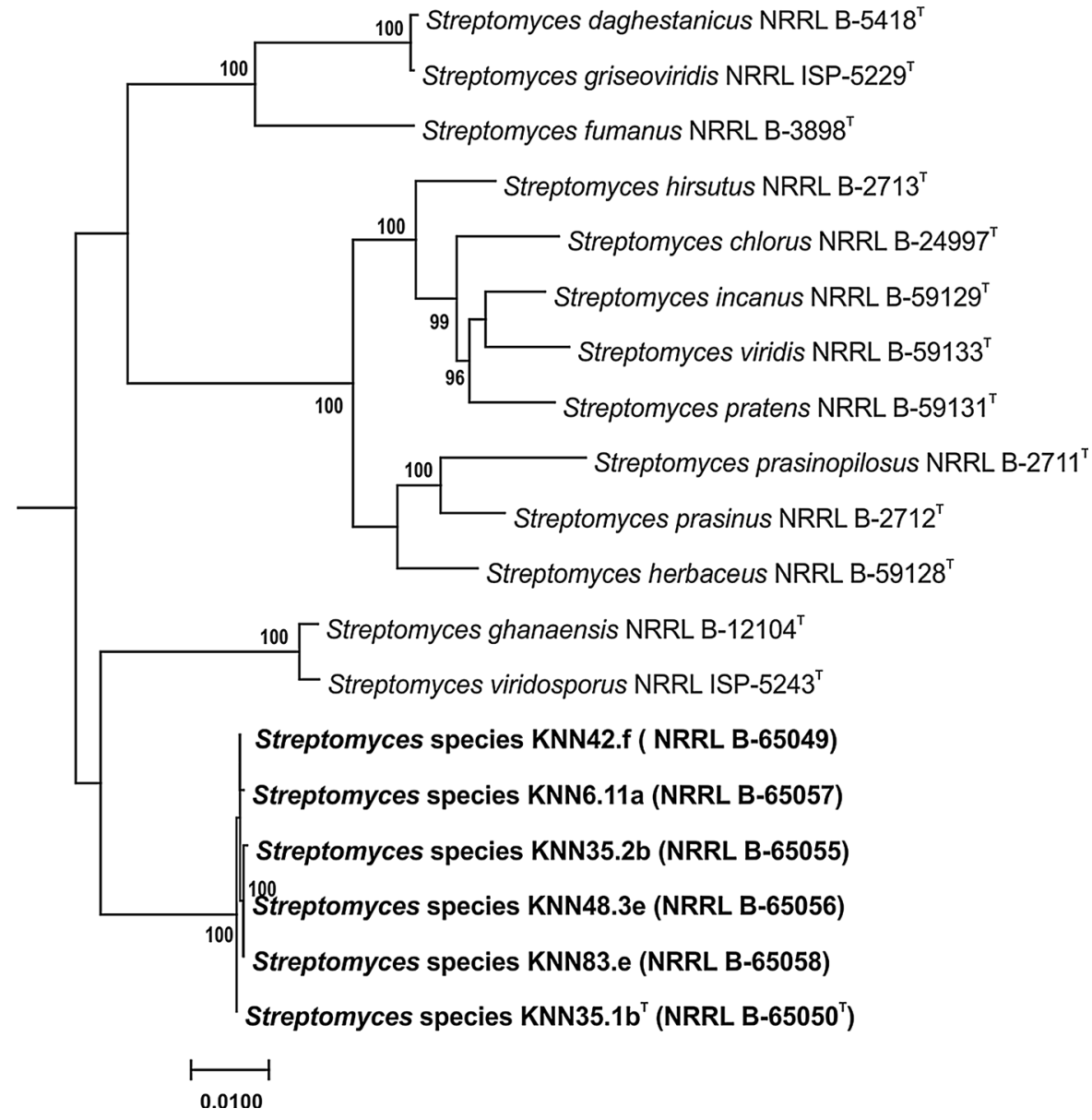

isoprenologs seen in isolates $\mathrm{KNN} 35.1 \mathrm{~b}$ and KNN35.2 $b^{\mathrm{T}}$ were identified as MK9 $\left(\mathrm{H}_{6}\right)(\sim 35 \%)$, MK9 $\left(\mathrm{H}_{8}\right)(\sim 30 \%)$ and MK9 $\left(\mathrm{H}_{4}\right)(\sim 10 \%)$. All of these properties are consistent with the classification of the isolates in the genus Streptomyces (Kämpfer 2012; Idris et al. 2017b). Complex mixtures of saturated and branched chain fatty acids were found in the representative isolates and in the type strain of $S$. ghanaensis (Table 3). The predominant components in all of these organisms were found to be anteiso$\mathrm{C}_{15: 0}(11.5-17.8 \%)$ and iso- $\mathrm{C}_{16: 0}(21.3-32.6 \%)$; quantitative differences were seen in these and other components while some of the minor fatty acids were discontinuously distributed, as exemplified by the presence of anteiso- $\mathrm{C}_{17: 1}$ and $\mathrm{C}_{17: 1}$ cis 9 in the $S$. ghanaensis type strain and anteiso- $\mathrm{C}_{18: 0}$ amongst the isolates.

Identical results were obtained for nearly all of the duplicated strains included in the phenotypic tests, whilst the exceptions were a few of the carbon source features recorded from the GENIII microplates (Table 4). It can also be seen from Table 4 that the isolates can be distinguished from one another showing that they are not clones. In addition, several properties distinguished all of the isolates from the type strain of $S$. ghanaensis (Table 4). Thus, only the Atacama isolates produced $N$-acetyl- $\beta$-glucosaminidase, oxidised L-arginine, butyric acid, L-keto-butryric acid, citric acid, D-and L-fucose and D-sorbitol and grew in the presence of $4 \%$, w/v sodium chloride, potassium tellurite and rapamycin SV and at $10^{\circ} \mathrm{C}$. In contrast, only $S$. ghanaensis NRRL B-12104 ${ }^{\mathrm{T}}$ oxidised $N$-acetyl- $\beta$-Dmannosamine, $N$-acetyl-neuraminic acid and D-glucuronic acid. It is also apparent from Table 4 that all of the strains have many phenotypic properties in common.

Isolates $\mathrm{KNN} 35.1 \mathrm{~b}^{\mathrm{T}}$ and $\mathrm{KNN} 35.2 \mathrm{~b}$ were found to inhibit the growth of the wild type strains of B. subtilis, 


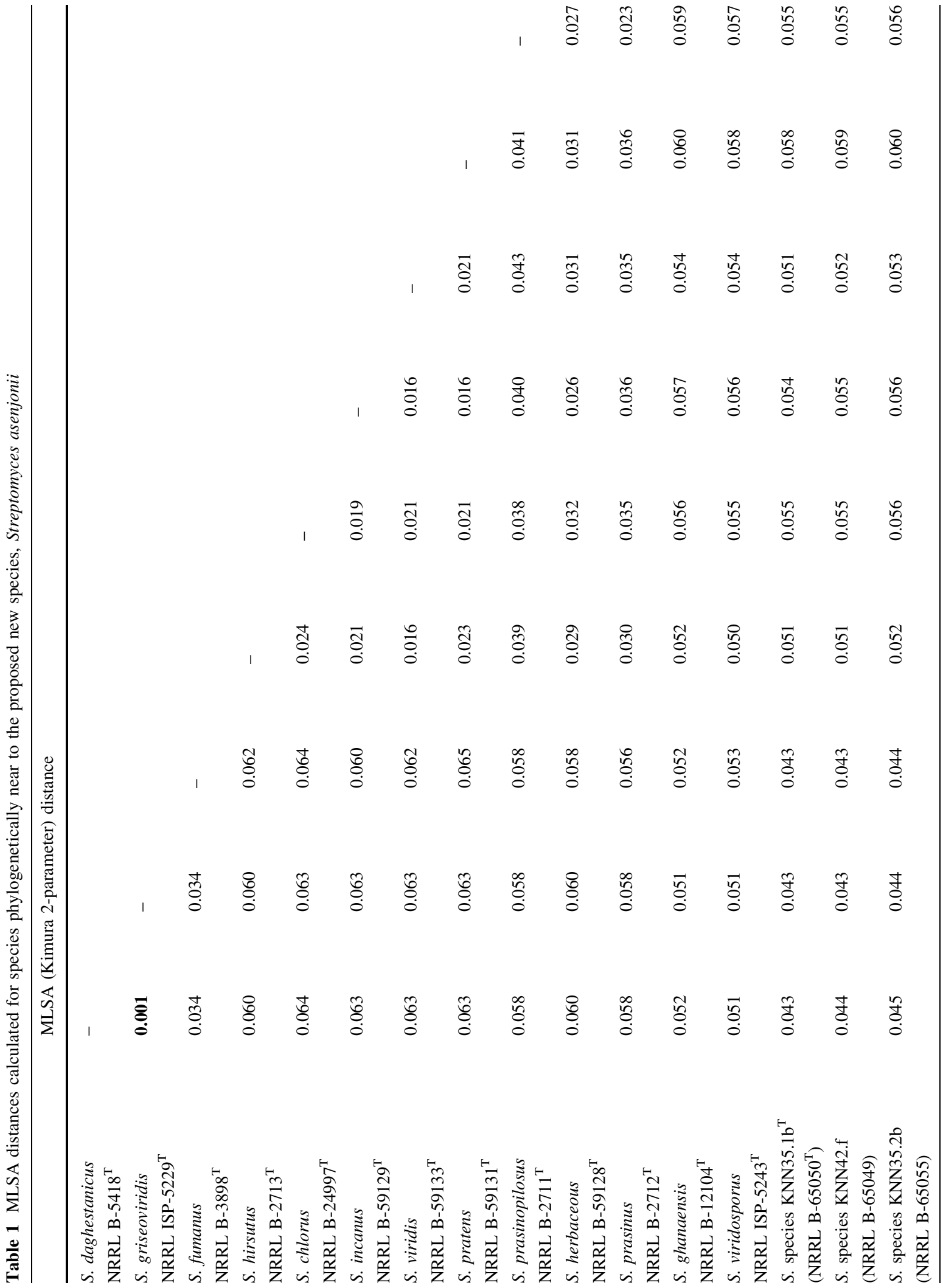




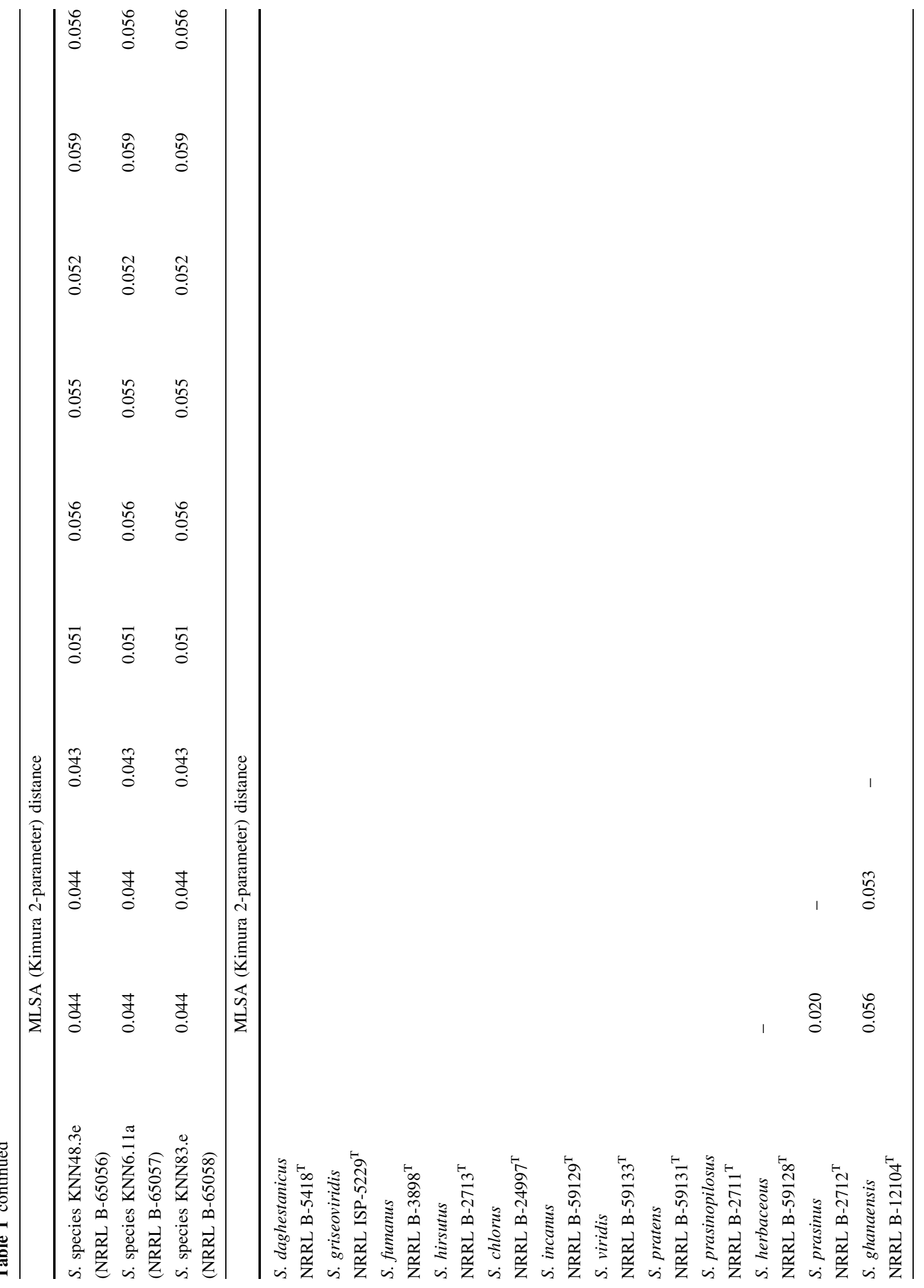




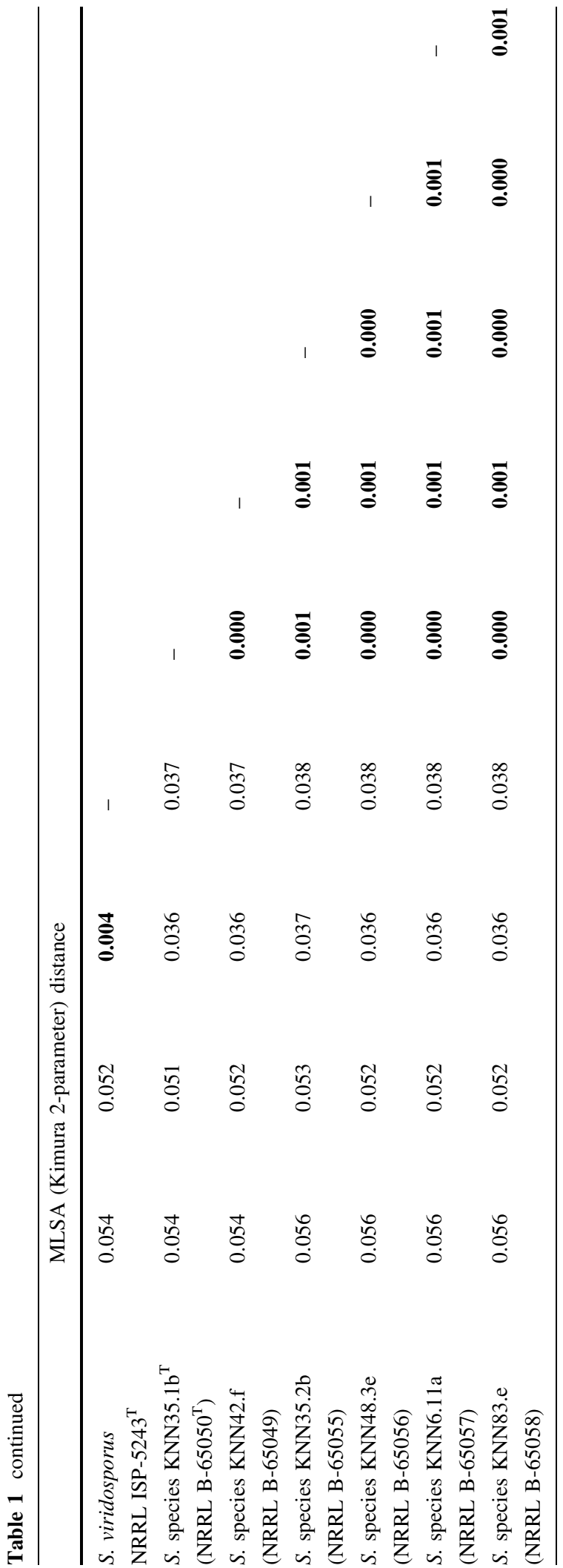

E. coli, P. fluorescens and S. aureus, whilst isolates KNN6.11a and KNN83.b only inhibited the growth of the $B$. subtilis strains; in all cases inhibition zones were extensive ranging from 13 to $24 \mathrm{~mm}$.

It can be concluded that the six isolates from the hyper-arid Atacama Desert soils have identical or almost identical 16S rRNA and MLSA gene sequences and share many phenotypic features in common, some of which distinguish them from the type strain of $S$. ghanaensis, their close phylogenetic neighbour in the Streptomyces MLSA gene tree generated from the five housekeeping genes. It is, therefore, proposed that the isolates be recognised as a new species within the genus Streptomyces, named Streptomyces asenjonii sp. nov. It seems likely that $S$. asenjonii strains are common in hyper-arid Atacama Desert soils as additional isolates from the Salar de Atacama sampling site show the same aerial/substrate mycelial and diffusible pigment colours as the current isolates when grown on oatmeal agar. Colour groups such as these have been shown to be reliable indicators of Streptomyces species identity (Antony-Babu et al. 2010; Goodfellow and Fiedler 2010).

It is evident from Table 1 that the type strains of $S$. ghanaensis and $S$. viridosporus have a low MLSA distance consistent with their assignment to a single genomic species. Indeed, in their extensive MLSA study of type strains of the family Streptomycetaceae, Labeda et al. (2017) noted that S. ghanaensis NRRL B-12104 ${ }^{\mathrm{T}}$ (also ATCC $14672^{\mathrm{T}}$ ) is a later synonym of $S$. viridosporus NRRL ISP-5243 ${ }^{\mathrm{T}}$. This observation was confirmed by determination of the ANIm and ANIb average-nucleotide identity values between draft genome sequences of the type strains of these species using the calculate_ani.py script (https://github.com/ widdowquinn/scripts/blog/master/bioinformatics/calc ulate_ani.py), as shown in Table S1. Note that the ANIm percentages between the genome sequences of S. viridosporus NRRL $2414^{\mathrm{T}}$, S. viridosporus T7A and S. ghanaensis ATCC $14672^{\mathrm{T}}$ are $>96 \%$ and the ANIb percentages between these genomes are $>97 \%$ which is indicative of species level relatedness (Richter and Rosselló-Móra 2009). Thus, according to Rule 38 of the Bacteriological Code of Nomenclature of Bacteria (Lapage et al. 1992; Parker et al. 2015), S. viridosporus Pridham et al. 1958 has priority over S. ghanaensis Wallhäuser et al. 1965. The type strains of these taxa form spiral chains of spiny to hairy spores (Kämpfer 2012), properties known to be predictive in 
Table 2 Growth and cultural characteristics of all of the isolates on ISP media after incubation for 14 days at $28{ }^{\circ} \mathrm{C}$

\begin{tabular}{lllll}
\hline Media & Growth & Substrate mycelium colour & Aerial spore mass colour & Diffusible pigment \\
\hline Glycerol-asparagine agar (ISP 5) & +++ & Dark grey & Dark grey & None \\
Inorganic salts-starch agar (ISP 4) & +++ & Yellowish white & Light yellowish orange & Light yellowish orange \\
Oatmeal agar (ISP 3) & ++++ & Yellowish white & Light yellowish orange & Light yellowish orange \\
Peptone-yeast extract-iron agar (ISP 6) & +++ & Yellowish grey & Olivaceous grey green & Yellowish grey \\
Tryptone-yeast extract agar (ISP1 ${ }^{\mathrm{a}}$ ) & +++ & Yellowish white & Light yellowish orange & Light yellowish orange \\
Tyrosine agar (ISP 7) & +++ & Yellowish white & Light yellowish orange & Light yellowish orange \\
Yeast extract-malt extract agar (ISP 2) & ++++ & White & Dark yellowish orange & Yellowish grey \\
\hline
\end{tabular}

++++ abundant growth; +++ very good growth

a ISP1 agar medium

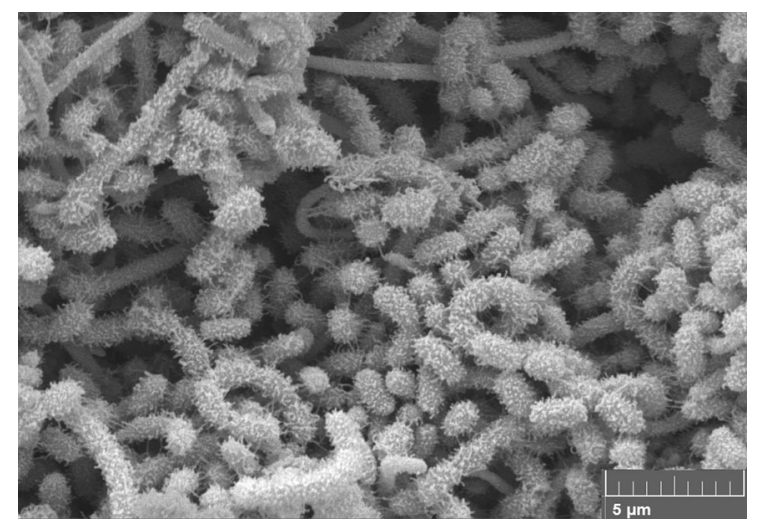

Fig. 3 Scanning electron micrograph of isolate $\mathrm{KNN} 35-1 \mathrm{~b}^{\mathrm{T}}$ showing hairy ornamented spores in open spirals following growth on oatmeal agar at $28{ }^{\circ} \mathrm{C}$ for 14 days. Bar $1 \mu \mathrm{m}$

Streptomyces systematics (Labeda et al. 2012) and have many physiological features in common (Kämpfer et al. 1991). Consequently, on the basis of these observations an emended description is given of Streptomyces viridosporus Pridham et al. (1958).

Description of Streptomyces asenjonii sp. nov.

Streptomyces asenjonii (a.sen.jo'ni.i. N.L. gen. n., asenjonii, named after Juan A. Asenjo in recognition of his promotion of work on Atacama Desert actinobacteria).

Aerobic, Gram-positive actinobacteria which form an extensively branched substrate mycelium which carry aerial hyphae that differentiate into open spirals of hairy ornamented spores. Grows from 10 to $50{ }^{\circ} \mathrm{C}$, optimally $37{ }^{\circ} \mathrm{C}$; from pH 5 to 11 , optimally 7.5 ; and in the presence of up to $5 \% \mathrm{w} / \mathrm{v}$ sodium chloride.
Produces acid and alkaline phosphatase, cysteine arylamidase, esterase lipase (C8), $\beta$-galactosidase, $N$-acetyl- $\beta$-glucosaminidase and leucine and valine arylamidases (API ZYM tests), hydrolyses aesculin and arbutin, degrades adenine, elastin, hypoxanthine, starch, L-tyrosine and Tweens 20, 40, 60 and 80 and is resistant to aztreonam. Additional phenotypic properties are given in Table 4 . The cell wall peptidoglycan contains $L L$-diaminopimelic acid and whole cell hydrolysates contain glucose, mannose, ribose and xylose. The major fatty acid is $i s o$-hexadecanoic acid (iso- $\mathrm{C}_{16: 0}$ ) and the predominant menaquinones are $\operatorname{MK} 9\left(\mathrm{H}_{6}\right)$ and $\mathrm{MK} 9\left(\mathrm{H}_{8}\right)$. The polar lipid profile contains diphosphatidylglycerol, glycophospholipid, phosphatidylethanolamine, phosphatidylglycerol and phosphatidylinositol.

The type strain KNN $35.1 b^{\mathrm{T}}$ (NCIMB $15082^{\mathrm{T}}$ $=$ NRRL B-65050 ${ }^{\mathrm{T}}$ ) and strains KNN 6.11a, KNN 35.2b, KNN 42.f, KNN 48.3e and KNN 83.e were isolated from hyper-arid Atacama Desert soils. The GenBank/EMBL/DDBJ accession number for the $16 \mathrm{~S}$ rRNA gene sequence of strain $\mathrm{KNN} 35.1 \mathrm{~b}^{\mathrm{T}}$ is LT621750. The Digital Protologue database TaxoNumber for strain KNN $35.1 b^{T}$ is TA00093.

Emended description of Streptomyces viridosporus Pridham, Hesseltine and Benedict $1958,67^{\mathrm{AL}}$

\section{Heterotypic synonym: Streptomyces ghanaensis Wallhäusser, Nesemann, Präve and Steigler 1966, $734^{A L}$}

Most of the data are taken from Kämpfer et al. (1991) and Kämpfer (2012). 
Table 3 Fatty acid profiles (\%) of representatives Streptomyces isolates and the type strain of S. ghanaensis

\begin{tabular}{|c|c|c|c|c|}
\hline Fatty acids & Isolate $\mathrm{KNN} 35.1 \mathrm{~b}^{\mathrm{T}}$ & Isolate KNN 35.2b & Isolate $\mathrm{KNN} 42 . \mathrm{f}$ & S. ghanaensis NRRL B-12104 \\
\hline Iso- $\mathrm{C}_{14: 0}$ & 5.3 & 7.6 & 8.1 & 3.7 \\
\hline Anteiso- $\mathrm{C}_{15: 0}$ & 17.5 & 15.1 & 17.8 & 11.5 \\
\hline Iso- $\mathrm{C}_{15: 0}$ & 11.3 & 7.2 & 8.4 & 5.2 \\
\hline $\mathrm{C}_{16: 0}$ & 4.0 & - & 6.7 & 3.0 \\
\hline Iso- $\mathrm{C}_{16: 0}$ & 24.2 & 21.3 & 28.6 & 32.6 \\
\hline Iso- $\mathrm{H} \mathrm{C}_{16: 0}$ & 3.0 & 8.3 & - & - \\
\hline $\mathrm{C}_{16: 0}$ & - & 8.8 & - & 3.0 \\
\hline Iso- $\mathrm{H} \mathrm{C}_{16: 1}$ & - & - & 4.4 & 8.8 \\
\hline Iso- $\mathrm{C}_{17: 0}$ & 6.9 & 3.4 & 3.7 & 2.7 \\
\hline Anteiso- $\mathrm{C}_{17: 0}$ & 9.9 & 6.4 & 7.8 & 12.3 \\
\hline $\mathrm{C}_{17: 1} \mathrm{CIS} 9$ & - & - & - & 1.2 \\
\hline $\mathrm{C}_{17: 1} \omega 8 \mathrm{c}$ & 0.9 & - & 0.7 & 1.2 \\
\hline Anteiso- $\mathrm{C}_{17: 1} \omega 9 \mathrm{c}$ & 3.4 & 3.3 & 3.7 & 6.6 \\
\hline Anteiso $-\mathrm{C}_{17: 1}$ & - & - & - & 6.6 \\
\hline $\mathrm{C}_{17: 0}$ & 0.8 & - & 0.9 & 0.4 \\
\hline $\mathrm{C}_{17: 0}$ 10-methyl & - & - & - & 0.2 \\
\hline $\mathrm{C}_{18: 0}$ & 0.3 & 4.2 & 1.3 & - \\
\hline $\mathrm{C}_{18: 0} \omega 9 \mathrm{c}$ & - & - & - & - \\
\hline Iso- $\mathrm{H} \mathrm{C}_{18: 1}$ & 0.9 & - & - & 1.4 \\
\hline Summed feature 3 & 2.0 & 3.3 & 2.8 & 4.0 \\
\hline Summed feature 5 & & 6.1 & 1.7 & - \\
\hline Summed feature 9 & 6.6 & 5.1 & 3.0 & 3.8 \\
\hline
\end{tabular}

Trace proportions $(<0.9 \%)$ are only cited for strains where other fatty acids were found at levels beyond this cut-off point

Summed feature $3, \mathrm{C}_{16: 1} \omega 7 \mathrm{cand} / \mathrm{orC}_{16: 1} \omega 6 \mathrm{c}$; summed feature 5 , iso- $\mathrm{C}_{17: 1} \omega 9 \mathrm{c}$ and/or $\mathrm{C}_{18: 2} \omega 6,9 \mathrm{c}$; summed feature 9 , iso- $\mathrm{C}_{19} \omega 8 \mathrm{a}$ and/or iso- $\mathrm{C}_{17: 1} \omega 9 \mathrm{c}$

Aerobic, Gram-stain positive actinobacteria that form substrate mycelia which bear a green aerial spore mass on glycerol-asparagine, salts-starch, oatmeal and yeast extract-malt extract agars. Short chains of over 10 spores are formed on these media. Spore surfaces are spiny to hairy. Melanoid pigments are not formed on peptone-yeast extract-iron or tyrosine agar or in tryptone-yeast broth. L-arabinose, D-cellobiose, Dfructose, D-galactose, D-glucose, D- glucosamine, glycogen, D-maltose, D-mannitol, D-mannose, starch, D-trehalose, D-xylose, acetate, fumarate, and pyruvate are used as sole carbon sources, but not myo-inositol, D-tagatose or D-turanose.

The source of the type strain NRRL ISP- $5243^{\mathrm{T}}$ $=$ NRRL $2414^{\mathrm{T}}$ is not known; 'S. ghanaensis' NRRL B-12104 was isolated from soil from Ghana.

The type strain is ATCC $27479=\mathrm{CBS}$ $654.72=\mathrm{BCRC}$ (formerly CCRC) $11870=\mathrm{CCUG}$ $37512=$ DSM $\quad 40243=$ NBRC $\quad 13353=$ IMET $43514=\mathrm{JCM} \quad 4859=\mathrm{KCTC} \quad 9145=\mathrm{NCIMB}$ $9824=$ NRRL $\quad 2414=$ NRRL-ISP $5243=$ RIA $1314=$ VKM Ac-1769 = VKM Ac-618. 
Table 4 Phenotypic tests that distinguish the isolates from one another and from Streptomyces ghanaensis NRRL B-12104 ${ }^{\mathrm{T}}$

\begin{tabular}{|c|c|c|c|c|c|c|c|}
\hline Characteristic & $\begin{array}{l}\text { Isolate } \mathrm{KNN} \\
6.11 \mathrm{a}\end{array}$ & $\begin{array}{l}\text { Isolate KNN } \\
35.1 \mathrm{~b}^{\mathrm{T}}\end{array}$ & $\begin{array}{l}\text { Isolate KNN } \\
35.2 \mathrm{~b}\end{array}$ & $\begin{array}{l}\text { Isolate } \\
\text { KNN 42.f }\end{array}$ & $\begin{array}{l}\text { Isolate } \\
\text { KNN 43.e }\end{array}$ & $\begin{array}{l}\text { Isolate } \\
\text { KNN 83.e }\end{array}$ & $\begin{array}{l}\text { S. ghanaensis NRRL } \\
\text { B-12104 }\end{array}$ \\
\hline \multicolumn{8}{|l|}{ API ZYM tests } \\
\hline $\begin{array}{l}N \text {-Acetyl- } \beta \text { - } \\
\text { glucosaminidase }\end{array}$ & + & + & + & + & + & + & - \\
\hline Esterase $(\mathrm{C} 4)$ & + & - & - & - & - & + & - \\
\hline$\alpha$-Glucuronidase & + & - & + & - & - & + & + \\
\hline$\alpha$-Mannosidase & - & + & - & + & - & - & + \\
\hline \multirow{2}{*}{\multicolumn{8}{|c|}{$\begin{array}{l}\text { GEN III BIOLOG microplate tests } \\
\text { (a) Oxidation of sugars }\end{array}$}} \\
\hline & & & & & & & \\
\hline $\begin{array}{l}N \text {-acetyl-D- } \\
\text { galactosamine }\end{array}$ & + & - & - & - & - & + & + \\
\hline $\begin{array}{l}N \text {-acetyl- } \beta \text {-D- } \\
\text { mannosamine }\end{array}$ & - & - & - & - & - & - & + \\
\hline $\begin{array}{l}N \text {-acetyl- } \\
\text { neuraminic } \\
\text { acid }\end{array}$ & - & - & - & - & - & - & + \\
\hline D-Fucose & + & + & + & + & + & + & - \\
\hline L-Fucose & + & + & + & + & + & + & - \\
\hline $\begin{array}{l}\text { D-Glucose-6- } \\
\text { phosphate }\end{array}$ & - & + & - & + & - & - & + \\
\hline$\alpha$-D-Lactose & + & + & + & - & + & - & + \\
\hline D-Mannitol & + & + & + & - & + & - & + \\
\hline $\begin{array}{l}\beta \text {-methyl-D- } \\
\text { Glucoside }\end{array}$ & + & + & - & - & - & - & - \\
\hline D-Salicin & + & - & - & - & - & + & + \\
\hline D-Sorbitol & + & + & + & + & + & + & - \\
\hline \multicolumn{8}{|c|}{ (b) Oxidation of amino acids } \\
\hline L-Arginine & + & + & + & + & + & + & - \\
\hline L-Serine & + & + & - & + & - & - & + \\
\hline \multicolumn{8}{|c|}{ (c) Oxidation of organic acids } \\
\hline $\begin{array}{l}\text { Bromo-succinic } \\
\text { acid }\end{array}$ & + & + & - & - & - & - & - \\
\hline Butyric acid & + & + & + & + & + & + & - \\
\hline $\begin{array}{l}\alpha \text {-keto-Butyric } \\
\text { acid }\end{array}$ & + & + & + & + & + & + & - \\
\hline Citric acid & + & + & + & + & + & + & - \\
\hline $\begin{array}{l}\alpha \text {-keto-Glutaric } \\
\text { acid }\end{array}$ & + & - & - & + & + & + & + \\
\hline $\begin{array}{l}\text { D-Glucuronic } \\
\text { acid }\end{array}$ & - & - & - & - & - & - & + \\
\hline $\begin{array}{l}\alpha \text {-hydroxy- } \\
\text { Butyric acid }\end{array}$ & + & - & - & + & - & - & - \\
\hline L-Lactic acid & + & - & - & + & - & - & - \\
\hline L-Malic acid & + & - & + & + & + & + & - \\
\hline Methyl pyruvate & - & - & - & + & - & - & - \\
\hline $\begin{array}{l}\text { L-Pyroglutamic } \\
\text { acid }\end{array}$ & + & + & + & + & + & - & - \\
\hline
\end{tabular}


Table 4 continued

\begin{tabular}{|c|c|c|c|c|c|c|c|}
\hline Characteristic & $\begin{array}{l}\text { Isolate KNN } \\
6.11 \mathrm{a}\end{array}$ & $\begin{array}{l}\text { Isolate KNN } \\
35.1 b^{T}\end{array}$ & $\begin{array}{l}\text { Isolate } \mathrm{KNN} \\
35.2 \mathrm{~b}\end{array}$ & $\begin{array}{l}\text { Isolate } \\
\text { KNN 42.f }\end{array}$ & $\begin{array}{l}\text { Isolate } \\
\text { KNN 43.e }\end{array}$ & $\begin{array}{l}\text { Isolate } \\
\text { KNN 83.e }\end{array}$ & $\begin{array}{l}\text { S. ghanaensis NRRL } \\
\text { B- } 12104^{\mathrm{T}}\end{array}$ \\
\hline \multicolumn{8}{|c|}{ (d) Resistance to inhibitory compounds } \\
\hline Lincomycin & + & - & - & - & - & + & - \\
\hline $\begin{array}{c}\text { Potassium } \\
\text { tellurite }\end{array}$ & + & + & + & + & + & + & - \\
\hline Rifamycin SV & + & + & + & + & + & + & - \\
\hline $\begin{array}{l}\text { Sodium chloride } \\
(4 \%, \mathrm{w} / \mathrm{v})\end{array}$ & + & + & + & + & + & + & - \\
\hline $\begin{array}{l}\text { Sodium lactate } \\
(1 \%)\end{array}$ & + & + & - & + & + & + & - \\
\hline Tetrazolium blue & + & - & - & - & - & + & - \\
\hline $\begin{array}{l}\text { Tetrazolium } \\
\text { violet }\end{array}$ & + & - & - & - & - & + & - \\
\hline Troleandomycin & + & - & - & - & - & + & - \\
\hline (e) Growth at & & & & & & & \\
\hline $\mathrm{pH} 5$ & + & + & - & - & + & + & - \\
\hline \multicolumn{8}{|l|}{ Degradation test } \\
\hline Casein & + & + & - & - & - & - & - \\
\hline \multicolumn{8}{|l|}{ Growth at } \\
\hline $10^{\circ} \mathrm{C}$ & + & + & + & + & + & + & - \\
\hline $45^{\circ} \mathrm{C}$ & _ & - & - & + & - & + & - \\
\hline
\end{tabular}

+ positive result; - negative result

Positive results recorded for all of the isolates and the $S$. ghanaensis type strain:API ZYM tests: acid and alkaline phosphatases, cysteine arylamidase, esterase lipase (C8), $\beta$-galactosidase, leucine and valine arylamidasesGEN III BIOLOG microplate tests: utilization of D-alanine, L-glutamic acid, L-histidine, inosine (amino acids), $N$-acetyl-D-glucosamine (amino-monosaccharide), glycylL-proline (dipeptide), acetic acid, acetoacetic acid, $\gamma$-amino-L-butyric acid, $p$-hydroxy-phenylacetic acid, D-malic acid, propionic acid (organic acids), gelatin (polymer), D-cellobiose, dextrin, D-fructose, D-galactose, $\beta$-gentiobiose, D-glucose, 3- $O$-methyl-D-glucose, Dmaltose, D-mannose, D-melibiose, sucrose, D-trehalose, D-turanose (sugars), D-galacturonic acid, L-galacturonic acid-Ý-lactone, Dgluconic acid, $\beta$-hydroxy-butyric acid (sugar acids), D-arabitol, glycerol, myo-inositol (sugar alcohols), growth at pH6, resistance to aztreonam, guanidine hydrochloride, lincomycin, nalidixic acid, niaproof and growth in the presence of, sodium bromate, and sodium formate $(1 \%, \mathrm{w} / \mathrm{v})$ Other phenotypic tests: aesculin and arbutin hydrolysis, degradation of adenine, elastin, hypoxanthine, starch, Ltyrosine, Tweens 40, 60 and 80 and growth at 20, 30 and $40{ }^{\circ} \mathrm{C}$ Negative results recorded for all of the isolates and for the $S$. ghanaensis type strain:API ZYM tests: $\alpha$-chymotrypsin, $\alpha$-fucosidase, $\alpha$-galactosidase, $\beta$-glucosidase, $\beta$-glucuronidase, lipase (C14) and naphthol-AS-BI-phosphohydrolaseGEN III BIOLOG microplate tests: utilization of D-aspartic acid, D-serine \#1, D-serine \#2 (amino acids), D-fructose-6-phosphate, stachyose (sugars), glucuronamide (amine hexose), D-lactic acid methyl ester, mucic acid, quinic acid, D-saccharic acid (organic acids), pectin (polymer) and resistance to fusidic acid and minocyclineOther phenotypic tests: allantoin and urea hydrolysis, nitrate reduction, $\mathrm{H}_{2} \mathrm{~S}$ production, degradation of cellulose, chitin, guanine, tributyrin, uric acid, xanthine, xylan and growth in the presence of sodium chloride $(8 \%, \mathrm{w} / \mathrm{v})$ and at 4 and $50{ }^{\circ} \mathrm{C}$ Non-reproducible results recorded for all of the strains:GEN III BIOLOG microplate tests: utilisation of D- raffinose (trisaccharide), L-rhamnose (monosaccharide), L-alanine, L-aspartic acid (amino acids), citric acid, formic acid, $\alpha$-keto-glutaric acid (organic acids), Tween 40 (surfactant); resistance to vancomycin (antibiotic), lithium chloride (heavy metal) and growth in presence of sodium butyrate (salt)

Acknowledgements $\mathrm{KB}$ and $\mathrm{HI}$ are grateful to the Thai and Malaysian Governments, respectively for PhD scholarships, IN for a postdoctoral fellowship from Newcastle University and ATB and MG for Emeritus Fellowships from the Leverhulme Trust. Mention of trade names or commercial products in this publication is solely for the purpose of providing specific information and does not imply recommendation or endorsement by the U.S. Department of Agriculture. USDA is an equal opportunity provider and employer. DPL and the ARS Culture Collection CRIS project was supported by ARS National Program 301.

Conflict of interest The authors declare that they have no conflicts of interest. 
Ethical statement This article does not contain any studies with human participants and/or animals performed any of the authors. Formal consent is not required in this study.

Open Access This article is distributed under the terms of the Creative Commons Attribution 4.0 International License (http:// creativecommons.org/licenses/by/4.0/), which permits unrestricted use, distribution, and reproduction in any medium, provided you give appropriate credit to the original author(s) and the source, provide a link to the Creative Commons license, and indicate if changes were made.

\section{References}

Antony-Babu S, Stach JEM, Goodfellow M (2010) Computerassisted numerical analysis of colour-group data for dereplication of streptomycetes for bioprospecting and ecological purposes. Antonie Van Leeuwenhoek 9(7):231239. doi:10.1007/s10482-009-9404-x

Boubetra D, Sabaoua N, Zitouni A, Bijani C, Lebrihi A, Mathieu F (2013) Taxonomy and chemical characterisation of new antibiotics produced by Saccharothrix SA 198 isolated from a Saharan soil. Microbiol Res 168:223-230

Bull AT, Asenjo JA (2013) Microbiology of hyper-arid environments: recent thoughts from the Atacama Desert, Chile. Antonie Van Leeuwenhoek 103:1173-1179

Bull AT, Asenjo JA, Goodfellow M, Gómez-Silva B (2016) The Atacama Desert: technical resources and the growing importance of novel microbial diversity. Ann Rev Microbiol 70:215-234. doi:10.1146/annurev-micro-102215095236

Busarakam K, Bull AT, Girard G, Labeda DP, van Wezel GP, Goodfellow M (2014) Streptomyces leeuwenhoekii sp. nov., the producer of chaxalactins and chaxamycins, forms a distinct branch in Streptomyces gene trees. Antonie van Leeuwenhoek 105:849-861. doi:10.1007/s10482-0140139-y

Busarakam K, Bull AT, Trujillo ME, Riescu R, Sangal V, van Wezel GP, Goodfellow M (2016a) Modestobacter caceserii sp.nov., novel actinobacteria with an insight into their adaptive mechanisms for survival in extreme hyper-arid Atacama Desert soils. Appl Microbiol 39:243-251

Busarakam K, Brown R, Bull AT, Tan GYA, Zucchi TD, da Silva LJ, de Souza WR, Goodfellow M (2016b) Classification of thermophilic actinobacteria isolated from arid desert soils, including the description of Amycolatopsis deserti sp.nov. Antonie van Leewuenhoek 109:319-334

Collins MD, Goodfellow M, Minnikin DE, Alderson G (1985) Menaquinone composition of mycolic acid-containing actinomycetes and some sporoactinomycetes. J Appl Bacteriol 58:77-86. doi:10.1111/j.1365-2672.1985.tb01431.x

Edgar RC (2004) MUSCLE: multiple sequence alignment with high accuracy and high through put. Nucleic Acids Res 32:1792-1797

Elsayed SS, Trusch F, Deng H, Raab A, Prokes I, Busarakam K, Asenjo JA, Andrews BA, van West P, Bull AT, Goodfellow M, Yi Y, Ebel R, Jaspars M, Rateb M (2015) Chaxapeptin, a lasso peptide from extremotolerant Streptomyces leeuwenhoekii strain C58 from the hyperarid Atacama Desert. J Org Chem 80:10252-10260

Felsenstein J (1981) Evolutionary trees from DNA sequences: A maximum likelihood approach. J Mol Evol 17:368-376

Felsenstein J (1985) Confidence limits on phylogenies: an approach using the bootstrap. Evolution 39:783-791

Fiedler H-P (2004) Screening for bioactivity. In: Bull AT (ed) Microbial diversity and bioprospecting. American Society of Microbiology, Washington, DC, pp 324-335

Fitch WM (1971) Towards defining the course of evolution: minimum change for a specific tree topology. Syst Zool 20:400-416

Goloboff PA, Farris JS, Nixon KC (2008) TNT, a free program for phylogenetic analysis. Cladistics 24:774-786

Goodfellow M, Fiedler HP (2010) A guide to successful bioprospecting: informed by actinobacterial systematics. Antonie van Leeuwenhoek 98:119-142

Goris J, Konstantinidis KT, Klappenbach JA, Coenye T, Vandamme P, Teidje JM (2007) DNA-DNA hybridization values and their relationship to whole-genome sequence similarities. Int J Syst Evol Microbiol 57:81-91

Guo Y, Zheng W, Rong X, Huang Y (2008) A multilocus phylogeny of the Streptomyces griseus 16S rRNA gene clade: use of multilocus gene analyses for streptomyces systematics. Int J Syst Evol Microbiol 58:149-159

Guo X, Liu N, Li X, Ding Y, Shang F, Gao Y, Ruan J, Huang Y (2015) Red soils harbor diverse culturable actinomycetes that are promising sources of novel secondary metabolites. Appl Environ Microbiol 81:3086-3103

Hayakawa M, Nonomura H (1987) Humic acid vitamin agar: a new medium for the selective isolation of soil actinomycetes. J Ferm Technol 65:501-509

Hong K, Gao A, Xie Q, Gao H, Zhuang L, Lin H, Yu H, Li J, Yao X, Goodfellow M, Ruan J (2009) Actinomycetes for marine drug discovery isolated from mangrove soils and plants in China. Mar Drugs 7:24-44

Idris H, Nouioui I, Asenjo JA, Bull AT, Goodfellow M (2017a) Lentzia chajnantorensis sp.nov., a very high altitude actinobacterium isolated from Cerro Chajnantor gravel soil in northern Chile. Antonie van Leeuwenhoek. doi:10.1007/ s10482-017-0851-5

Idris H, Labeda DP, Nouioui I, Castro JF, Montero-Calasanz MC, Bull AT, Asenjo JA, Goodfellow M (2017b) Streptomyces aridus sp.nov., isolated from a high altitude Atacama Desert soil and emended description of Streptomyces noboritoensis Isono et al. 1957. Antonie van Leeuwenhoek 110(5):705-717. doi:10.1007/s10482-017-0838-2

Kämpfer P (2012) Genus Streptomyces. In: Goodfellow M, Kämpfer P, Busse HJ, Trujillo ME, Suzuki KI, Ludwig W, Whitman WB (eds) Bergey's manual of systematic bacteriology, vol 5, 2nd edn. The Actinobacteria, Part B. Springer, New York, pp 1455-1767

Kämpfer P, Kroppenstedt RM, Dott W (1991) A numerical classification of the general Streptomyces and Streptoverticillium using miniaturized physiological tests. J Gen Microbiol 137:1331-1891

Kelly KL (1964) Centroid notations for revised ISCC-NBS colour name blocks. J Res Nat Bur Stand USA 61:472

Kim SB, Goodfellow M (2002) Streptomyces thermospinisporus sp. nov., a moderately thermophilic carboxydotrophic streptomycete isolated from soil. Int J Syst Evol 
Microbiol 52:1225-1228. doi:10.1099/00207713-52-41225

Kimura M (1980) A simple method for estimating evolutionary rate of base substitutions through comparative studies of nucleotide sequences. J Mol Evol 16:111-120

Küster E, Williams ST (1964) Selection of media for isolation of streptomycetes. Nature 202:928-929

Labeda DP (2016) Taxonomic evaluation of putative Streptomyces scabiei strains held in the ARS Culture Collection (NRRL) using multi-locus sequence analysis. Antonie van Leeuwenhoek 109:349-356. doi:10.1007/s10482-0150637-6

Labeda DP, Goodfellow M, Brown R, Ward AC, Lanoot B, Vanncanneyt M, Swings J, Kim SB, Liu Z, Chun J, Tamura T, Oguchi A, Kikuchi T, Kikuchi H, Nishii T, Tsuji K, Yamaguchi Y, Tase A, Takahashi M, Sakane T, Suzuki KI, Hatano K (2012) Phylogenetic study of the species within the family Streptomycetaceae. Antonie van Leeuwenhoek 101:73-104

Labeda DP, Doroghazi JR, Ju KS, Metcalf WW (2014) Taxonomic evaluation of Streptomyces albus and related species using multilocus sequence analysis and proposals to emend the description of Streptomyces albus and describe Streptomyces pathocidini sp. nov. Int J Syst Evol Microbiol 64:894-900. doi:10.1099/ijs.0.058107-0

Labeda DP, Rong X, Huang Y, Doroghazi JR, Ju KS, Metcalf WW (2016) Taxonomic evaluation of species in the Streptomyces hirsutus clade using multi-locus sequence analysis and proposals to reclassify several species in this clade. Int J Syst Evol Microbiol 66:2444-2450

Labeda DP, Dunlap CA, Rong X, Huang Y, Duroghazi JR, Ju KS, Metcaff WW (2017) Phylogenetic relationships in the family Streptomycetaceae using multilocus sequence analysis. Antonie van Leeuwenhoek 10(4):563-583. doi:10.1007/s10482-016-0824-0

Lapage SP, Sneath PHA, Lessel EF, Skerman VBD, Seeliger HPR, Clark WA (1992) International code of nomenclature of bacteria (1990 revision). ASM Press, Washington, DC

Lechevalier MP, Lechevalier HA (1970) Chemical composition as a criterion in the classification of aerobic actinomycetes. Int J Syst Evol Microbiol 20:435-443. doi:10.1099/00207 713-20-4-435

Meier-Kolthoff JP, Auch AF, Klenk H-P, Göker M (2013a) Genome sequence-based species delimitation with confidence intervals and improved distance functions. BMC Bioinform 14:60

Meier-Kolthoff JP, Göker M, Spröer C, Klenk H-P (2013b) When should a DDH experiment be mandatory in microbial taxonomy? Arch Microbiol 195:413-418

Meier-Kolthoff JP, Hahnke RL, Petersen J, Scheuner C, Michael V, Fiebig A, Rohde C, Rohde M, Fartmann B, Goodwin LA, Chertkov O, Reddy T, Pati A, Ivanova N, Markowitz V, Kyrpides NC, Woyke T, Göker M (2014) Klenk H-P (2014) Complete genome sequence of DSM $30083^{\mathrm{T}}$, the type strain (U5/41T) of Escherichia coli, and a proposal for delineating subspecies in microbial taxonomy. Stand Genomic Sci 10:2

Meklat A, Sabaou N, Zitouni A, Mathieu F, Lebrihi F (2011) Isolation, taxonomy and antagonistic properies of halophilic actinomycetes in Saharan soils of Algeria. Appl Environ Microbiol 77:6710-6714
Minnikin DE, O’Donnell AG, Goodfellow M, Alderson G, Athalye M, Schaal A, Parlett JH (1984) An integrated procedure for the extraction of bacterial isoprenoid quinones and polar lipids. J Microbiol Methods 2:233-241

Murray PR, Boron EJ, Pfaller MA, Tenover FC, Yolken RH (1999) Manual of clinical microbiology, 7th edn. ASM Press, Washington, DC

Nachtigall J, Kulik A, Helaly S, Bull AT, Goodfellow M, Asenjo JA, Maier A, Wiese J, Imhoff JF, Süssmuth RD, Fiedler HP (2011) Atacamycins A-C, 22 membered antitumor macrolide derivatives produced by Streptomyces sp. C38. J Antibiot (Tokyo) 64:775-780

Nguyen L-T, Schmidt HA, von Haeseler A, Minh BQ (2015) IQTREE: a fast and effective stochastic algorithm for estimating maximum likelihood phylogenies. Mol Biol Evol 32:268-274

O'Donnell AG, Falconer C, Goodfellow M, Ward AC, Williams E (1993) Biosystematics and diversity amongst novel carboxydotrophic actinomycetes. Antonie Van Leeuwenhoek 64:325-340. doi:10.1007/Bf00873091

Okoro CK, Brown R, Jones AL, Andrews BA, Asenjo JA, Goodfellow M, Bull AT (2009) Diversity of culturable actinomycetes in hyper-arid soils of the Atacama Desert, Chile. Antonie van Leeuwenhoek 95:121-133. doi:10. 1007/s10482-008-9295-2

Okoro CK, Bull AT, Mutreja A, Rong X, Huang Y, Goodfellow M (2010) Lechevalieria atacamensis sp. nov., Lechevalieria deserti sp. nov. and Lechevalieria roselyniae sp. nov., isolated from hyperarid soils. Int J Syst Evol Microbiol 60:296-300

Parker CT, Tindall BJ, Garrity GM (2015) International code of nomenclature of prokaryotes. Prokaryotic code (2008 revision). Int J Syst Evol Microbiol. doi:10.1099/ijsem.0. 000778

Pattengale ND, Alipour M, Bininda-Emonds ORP, Moret BME, Stamatakis A (2010) How many bootstrap replicates are necessary? J Comput Biol 17:337-354

Pridham TG, Hesseltine CW, Benedict RG (1958) A guide for the classification of streptomycetes according to selected groups, placement of strains in morphological groups. Appl Microbiol 6:52-79

Rateb MF, Houssen WE, Arnold M, Abdelrahman MH, Deng H, Harrison WTA, Okoro CY, Asenjo JA, Andrews BA, Ferguson G, Bull AT, Goodfellow M, Ebel R, Jaspars M (2011a) Chaxamycins A-D, bioactive ansamycins from a hyper-arid desert Streptomyces sp. J Nat Prod 74:1491-1499

Rateb MF, Houssen WE, Harrison WTA, Deng H, Okoro CY, Asenjo JA, Andrews BA, Bull AT, Goodfellow M, Ebel R, Jaspars M (2011b) Diverse metabolic profiles of a Streptomyces strain isolated from a hyper-arid environment. J Nat Prod 74:1965-1971

Richter M, Rosselló-Móra R (2009) Shifting the genomic gold standard for the prokaryotic species definition. Proc Natl Acad Sci USA 106:19126-19131

Rong X, Huang Y (2010) Taxonomic evaluation of the Streptomyces griseus clade using multilocus sequence analysis and DNA:DNA hybridisation with proposal to combine 29 species and three subspecies as 11 genomic species. Int $\mathbf{J}$ Syst Evol Microbiol 60:696-703

Rong X, Huang Y (2012) Taxonomic evaluation of the Streptomyces hygroscopicus clade using multilocus sequence 
analysis and DNA-DNA hybridization, validating the MLSA scheme for systematics of the whole genus. Syst Appl Microbiol 35:7-18. doi:10.1016/j.syapm.2011.10. 004

Rong X, Huang Y (2014) Multi-locus sequence analysis: taking prokaryotic systematics to the next level. Methods Microbiol 41:221-251. doi:10.1016/bs.mim.2014.10.001

Santhanam R, Okoro CK, Huang Y, Bull AT, Andrews BA, Asenjo JA, Weon HY, Goodfellow M (2012a) Streptomyces deserti sp.nov., isolated from hyper-arid Atacama Desert soil. Antonie van Leeuwenhoek 101:575-581

Santhanam R, Okoro CK, Rong X, Huang Y, Bull AT, Wen HY, Andrews BA, Asenjo JA, Goodfellow M (2012b) Streptomyces atacamensis sp. nov., isolated from an extreme hyper-arid soil of the Atacama Desert. Chile. Int J Syst Evol Microbiol 62:2680-2684

Santhanam R, Rong X, Huang Y, Andrews BA, Asenjo JA, Goodfellow (2013) Streptomyces bullii sp.nov., isolated from a hyper-arid Atacama Desert soil. Antonie van Leeuwenhoek 103: 367-373

Sasser M (1990) Identification of bacteria by gas chromatography of cellular fatty acids. MIDI Technical Note 101, MIDI Inc., Newark, DE

Shirling EB, Gottlieb D (1966) Methods for characterization of Streptomyces species. Int J Syst Evol Microbiol 16: 313-340

Stamatakis A (2014) RAxML version 8: a tool for phylogenetic analysis and post-analysis of large phylogenies. Bioinformatics 30:1312-1313

Staneck JL, Roberts GD (1974) Simplified approach to identification of aerobic actinomycetes by thin-layer chromatography. Appl Microbiol 28:226-231

Swofford DL (2002) PAUP*: phylogenetic analysis using parsimony (*and other methods), Version 4.0 b10. Sinauer Associates, Sunderland

Tamura K, Stecher G, Peterson D, Filipski A, Kumar S (2013) MEGA6: molecular evolutionary genetics analysis version 6.0. Mol Biol Evol 30:2725-2729

Tan GYA, Ward AC, Goodfellow M (2006) Exploration of Amycolatopsis diversity in soil using genus-specific primers and novel selective media. Syst Appl Microbiol 29:557-569

Tiwari K, Gupta RK (2012) Rare actinomycetes: a potential storehouse for novel antibiotics. Crit Rev Biotech 32:108-132. doi:10.3109/07388551.2011.562482

Vaas LAI, Sikorski J, Michael V, Göker M, Klenk HP (2012) Visualization and curve-parameter estimation strategies for efficient exploration of phenotype microarray kinetics. PLoS ONE 7:e34846. doi:10.1371/journal.pone.0034846

Vaas LAI, Sikorski J, Hofner B, Fiebig A, Buddruhs N, Klenk HP, Göker M (2013) opm: an R package for analysing OmniLog ${ }^{\circledR}$ phenotype microarray data. Bioinformatics. doi:10.1093/bioinformatics/btt291

Wallhäuser KH, Nesemann G, Prave P, Steigler A (1965) Moenomycin, a new antibiotic 1. Fermentation and isolation. J Antimicrob Agents Chemother 1996:734-736

Wayne LG, Brenner DJ, Colwell RR, Grimont PAD, Kandler O, Krichevsky MI, Moore LH, Moore WEC, Murray RGE, Stackebrandt E, Starr MP, Trüper HG (1987) Report of the ad hoc committee on reconciliation of approaches to bacterial systematics. Int J Syst Bacteriol 37:463-464. doi:10. 1099/00207713-37-4-463

Wichner D, Idris H, Houssen WE, McEwan AR, Bull AT, Asenjo JA, Goodfellow M, Jaspars M, Ebel R, Rateb ME (2016) Isolation and anti-HIV-1 integrase activity of lentzeosides A-F from extremotolerant lentzea sp. H45, a strain isolated from a high-altitude Atacama Desert soil. J Antibiot doi:10.1038/ja.2016.78

Williams ST, Goodfellow M, Alderson G, Wellington EMH, Sneath PHA, Sackin MJ (1983) Numerical classification of Streptomyces and related genera. J Gen Microbiol 129: 1743-1813

Yoon SH, Ha SM, Kwon S, Lim J, Kim Y, Seo H, Chun J (2017) Introducing EzBioCloud: a taxonomically united database of 16S rRNA and whole genome assemblies. Int J Syst Evol Microbiol. doi:10.1099/ijsem.0.001755

Zakharova OS, Zenova GM, Zvyagintsey DG (2003) Some approaches to the selective isolation of actinomycetes of the genus Actinomadura from soil. Microbiology 72:110 113 